\title{
Peran Komunikasi Interpersonal Kepala Sekolah Mendorong Guru Sekolah Alam Bandung dalam Bekerja dan Berprestasi
}

\author{
Agus Daniar', Zahra Nurhaniza ${ }^{2}$ \\ ${ }^{1}$ Program Studi Magister Ilmu Komunikasi, Universitas Bunda Mulia, Jakarta, Indonesia \\ ${ }^{2}$ School of Business and Management, Institut Teknologi Bandung, Bandung, Indonesia \\ email: agusdnr@gmail.com¹, zzahranurhaniza@gmail.com²
}

Received : 01-06-2021, Revision : 14-06-2021, Acceptance : 30-06-2021, Published Online : 30-06-2021

\begin{abstract}
Abstrak
Model komunikasi interpersonal yang ditegaskan dalam penelitian berkaitan dengan peran kepala sekolah sebagai atasan yang semula adalah guru guru Sekolah Alam Bandung (SAB. Tujuan dari penelitian ini untuk mengungkap hubungan komunikasi interpersonal atasan bahawan terhadap keterlibatan guru SAB. Metode Survei diterapkan dalam riset ini dengan pendekatan kuantitatif yang diimplementasikan dalam teknik analisis Regresi Berganda. Sampling yang digunakan berupa sensus dengan mengambil seluruh sample sejumlah 34 guru. Dari hasil uji Koefisien Determinasi, ditemukan bahwa variabel Employee Engagement Driver memiliki dampak secara simultan baik kepada Engagement Behavior Stay dan Strive, dengan nilai masing-masing sebesar 92,2\% dan 83,8\%. Hasil perhitungan kombinasi uji-t dan the lowest average score membuktikan bahwa pengaruh komunikasi atasan terhadap kesediaan bawahan untuk tetap bekerja (Stay) dan berprestasi (Strive) di SAB lebih tinggi, dibandingkan dengan drivers lainnya seperti gaji, lingkungan kerja dan beban kerja. Hasil analisis menunjukkan Kepala Sekolah telah memenuhi harapan bawahan dan dinilai mampu menjadi atasan yang menghargai pendapat bawahannya dalam pengambilan keputusan, serta memberikan perhatian terhadap kinerja bawahannya.
\end{abstract}

Kata Kunci: Employee Engagement Drivers, Employee Engagement Behaviour, Komunikasi interpersonal, Model Peran

\begin{abstract}
The interpersonal communication model used in this study is related to the role of the principal as a superior who was originally a teacher at the Bandung Natural School (SAB). The goal of the study is to determine the connection between interpersonal communication from subordinates' superiors towards the involvement of SAB teachers. Quantitative analysis is implemented in the Multiple Regression analysis technique. The study used a census sampling technique by taking a total sample of 34 teachers. The results of the Coefficient of Determination test show that the Employee Engagement Driver variable has a simultaneous effect both on Engagement Behavior Stay and Strive, with scores of $92.2 \%$ and $83.8 \%$ respectively. The results of the calculation of the combination of the t-test and the lowest average score prove that the influence of superior communication on the willingness of subordinates to keep working (Stay) and excel (Strive) at SAB higher, banded compared with other drivers such as salaries, work environment, and workload. The results of the analysis show that the principal has met the expectations of his subordinates and is considered capable of being a superior who respects the opinions of his subordinates in making decisions and pays attention to the performance of his subordinates.
\end{abstract}

Keywords: Employee Engagement Drivers, Employee Engagement Behavior, Interpersonal Communication, Role Model 


\section{Pendahuluan}

Sekolah menjadi tempat paling berpengaruh kedua untuk menjalin hubungan dengan manusia lain selain keluarga, sehingga berperan penting untuk membangun karakter anak yang masing-masing berbeda. Peran sekolah dalam membangun karakter anak berhubungan juga dengan kinerja guru yang mendidik mereka (Marta et al., 2020). Relasi guru terhadap murid juga berperan penting dalam memastikan sarana pendidikan yang bersahabat. Sosok yang dikenal sebagai "Orang tua kedua" mendapatkan kesempatan untuk memberikan waktu untuk murid untuk mengimplementasikan hubungan orang tua dengan anak (Sasongko \& Marta, 2018). Dalam rangka memperluas pendidikan di Indonesia yang berkualitas tanpa berkompromi dengan harga, Lendo Novo membangun sebuah Sekolah Alam Bandung yang berdiri hingga saat ini.

Konsep Sekolah Alam di inisiasi oleh Lendo Novo dan telah diwujudkan secara nyata pada tahun 1998 di Ciganjur Jakarta, berawal dari pemikiran bahwa sekolah berkualitas tidak harus mahal. Menurut pandangan Lendo, mahalnya biaya Pendidikan karena adanya komponen infrastruktur yang tinggi, disisi lain faktor penting dari kualitas pendidikan sebenarnya ada pada guru, metode belajar dan buku-buku yang berkualitas. Oleh karena itu, infrastruktur kelas di Sekolah Alam umumnya dibuat dari kayu berupa panggung (tidak permanen) dan alam dijadikan sebagai media belajar. Penelitian Hamadani (2015) menyimpulkan bahwa keberadaan sekolah alam telah membawa angin segar ditengah banyaknya kasus kekerasan di sekolah (Hamadani, 2015). Sekolah alam dengan sistem pendidikannya mampu manghadirkan lingkungan yang ramah bagi anak. Tabah hati (2017) menyebutkan banyak siswa merasa cocok belajar di sekolah alam karena interaksi yang menyenangkan, dan murid dapat mengapresiasi kepribadian murid lain, baik kelebihan maupun kekurangan (Tabah Hati, 2017).

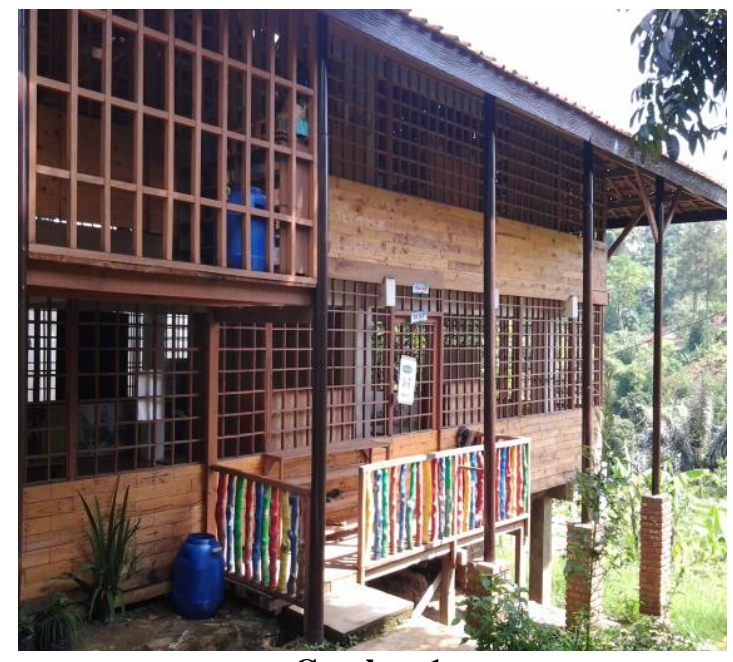

Gambar 1.

Model Kelas di Sekolah Alam Bandung 
Sekolah Alam Bandung (SAB) adalah salah satu sekolah yang menggunakan struktur Sekolah Alam yang dirintis Lendo Novo, yang didirikan tahun 2001 dengan jumlah awal 16 murid dan 4 guru. Saat ini telah berkembang menjadi 303 murid dari berbagai jenjang baik dari Pendidikan Taman Kanak- Kanak hingga Sekolah Menengah Atas (SMA) dengan jumlah guru sebanyak 59 orang.

Pertumbuhan jumlah siswa SAB pada periode terakhir meningkat 4,62\%, namun terjadi penurunan jumlah siswa pada tingkat Sekolah Menengah Atas (SMA). Sejalan dengan jumlah siswa, jumlah guru pada periode awal 2020/2021 telah mengalami peningkatan dibandingkan periode 2019/2020 (Budaya, 2020). Di sisi lain, rasio guru dan murid relatif stabil dalam dua tahun terakhir yaitu sebesar satu banding sembilan.

Menurut Kementerian Pendidikan dan Kebudayaan, rasio standar guru dan siswa adalah 1:24, sedangkan rasio guru dan siswa pada tahun 2020 di SAB adalah 1: 9 atau di bawah standar nasional. Selain itu target rasio guru dan siswa di SAB adalah 1:12, sehingga dapat disimpulkan bahwa jumlah siswa belum sesuai dengan target, atau setidaknya terdapat kapasitas yang masih tersedia untuk menambah jumlah siswa. Rasio ini menunjukkan adanya peluang pendapatan potensial dengan meningkatkan jumlah siswa.

SAB didirikan 20 tahun lalu, tetapi hanya lima guru yang tinggal selama lebih dari sepuluh tahun. Sebaliknya, mayoritas masa kerja guru ada di bawah 5 tahun sebesar 64,7\%, antara 5-10 tahun sebesar 20,65\%, dan hanya 15,7\% yang bekerja selama lebih dari 10 tahun. Artinya selama 20 tahun sejak berdirinya SAB terjadi pergantian guru yang relatif tinggi, setidaknya terjadi penurunan jumlah guru senior dari 16 menjadi 5 guru, meskipun relatif tidak terjadi pergantian guru dalam 3 tahun terakhir (Sari et al., 2018).

Dalam rangka mempertahankan kualitas pendidikan di SAB, maka mempertahankan guru adalah salah satu cara yang harus dilakukan, pernyataan ini diperkuat dari penelitian Totok Suprayitno dalam acara Diskusi dan Peluncuran Indeks Alibaca Tingkat Provinsi di Perpustakan Kemendikbud tgl 17 Mei 2019, animo generasi muda untuk menjadi guru masih rendah. Dari pertahanan kualitas pendidikan, akan melahirkan dimensi budaya yang dilahirkan dari lingkungan kerja guru (Fernando et al., 2020).

Upaya yang dilakukan agar guru tetap bertahan dan berprestasi, yang perlu diperhatikan tidak hanya yang berkaitan dengan gaji dan sarana prasarana untuk bekerja, namun faktor komunikasi menjadi faktor yang penting karena sekolah adalah bidang jasa dimana manusia memiliki peran sangat penting, komunikasi antara atasan (kepala sekolah) dan guru menjadi aspek utama yang perlu mendapatkan atensi khusus dari pihak sekolah (Riauan et al., 2020). Penelitian sebelumnya menunjukan bahwa sepertiga guru baru meninggalkan pekerjaannya 
dalam kurun waktu kurang dari 5 tahun karena berberapa alasan antara lain gaji yang rendah dibandingkan dengan pekerjaan lain, kondisi lingkungan kerja yang terkait dengan dukungan administrasi, dukungan persiapan dan peralatan mengajar, serta diabaikannya masukan dari para guru dalam pengambilan keputusan (Darling-Hammond, 2003). Penelitian ini akan difokuskan pada peran komunikasi atasan (kepada sekolah) dalam mempertahankan loyalitas dan semangat para guru dibandingkan dengan faktor loyalitas lainnya.

\section{Telaah Pustaka}

Studi menunjukkan bahwa sepertiga dari guru baru telah meninggalkan profesinya dalam waktu kurang dari 5 tahun (Darling-Hammond, 2003) karena beberapa alasan yaitu, gaji yang lebih rendah dibandingkan dengan pekerjaan lain, kondisi pekerjaan yang kurang mendukung dari sisi administratif dan perlengkapan untuk mengajar, serta kurang diperhatikanya masukan dari para guru dalam pengambilan keputusan.

Dari sisi profesi non guru, Tower Watson (2013) dari hasil penelitiannya yang berbasis di New York, menemukan $80 \%$ alasan karyawan mengundurkan diri didasari oleh nonfinansial, termasuk komunikasi atasan bawahan. Sedangkan menurut penelitian Payscale yang dikutip dari Kompas.com tanggal 23 Mei 2019, menemukan bahwa pengaruh utama pegawai keluar dari pekerjaanya antara lain adalah, ingin memperoleh gaji lebih tinggi atau tidak memiliki kesamaan nilai pribadi pada pekerjaannya. Masih dari penelitian Payscale, alasan lain mengapa orang berhenti bekerja adalah sikap atasan yang tidak menyenangkan, dimana $75 \%$ pekerja mengatakan atasan langsung menjadi penyebab stress mereka sehari- hari. Disamping itu menurut Asosiasi Psikologi Amerika, sekitar 50 prosen keluar dari pekerjaanya karena merasa tidak dihargai.

Teori dari penelitian yang dianggap relevan berkaitan dengan dengan komunikasi interpersonal, dan model Engagament Behavior dari Aon Hewit. Komunikasi interpersonal adalah interaksi verbal dan nonverbal antara dua orang atau lebih yang saling tergantung satu sama lain (Dewi \& Hidayat, 2014). Komunikasi interpersonal atasan bawahan adalah merupakan proses mengirim dan menerima pesan antara atasan dan bawahan, dilakukan dengan bertatap muka dan memiliki umpan balik dengan tujuan untuk memelihara suatu hubungan. Sereenonchai (2021) menunjuk pemimpin opini sebagai contoh kuat dalam komunikasi intrapersonal, mengingat dalam praktik, mereka mampu menggerakan perilaku orang luas dan menciptakan relasi yang kuat (Sereenonchai \& Arunrat, 2021).

Komunikasi interpersonal antar kepala sekolah dengan guru juga terjadi ketika Kepala sekolah mempengaruhi guru untuk meningkatkan kualitas belajar mengajar dengan melakukan 
dialog profesional dalam interaksi sekolah (Suherman \& Suhardan, 2019). Penelitian Rahayu (2017) terhadap guru-guru di Sekolah Menengah Pertama menemukan korelasi antara komunikasi interpersonal terhadap motivasi kerja yang bermanfaat dalam peningkatan kapabilitas guru untuk membangun kerjasama tim dan mengatasi permasalahan, baik oleh murid, teman kerja hingga atasan. (Rahayu, 2017) Dan ketrampilan komunikasi Kepala Sekolah ternyata dapat mempengaruhi kepuasan kerja (job satisfaction) para guru (Supriadi, 2017) serta komunikasi kepala sekolah juga memiliki dampak yang efektif terhadap kinerja guru (Murtiningsih et al., 2019). Penelitian Price (2012) menambahkan komunikasi interpersonal diantara Kepala Sekolah, menunjukkan hasil adanya peningkatan kepuasan kerja, kesamaan persepsi, dan komitmen (Price, 2012).

Budiman (2020) menggunakan model peranan (Role Model) sebagai model hubungan interpersonal. Model ini membahas hubungan interpersonal sebagai cara bersandiwara dan hubungan interpersonal akan terjalin apabila setiap anggota memainkan sandiwara sesuai dengan perannya (role expectation), tuntutan peran (role demands), keterampilan dalam bersandiwara (role skills) serta mampu menghindari konflik selama sandiwara (Rismi et al., 2020). Harapan terhadap peran seseorang akan berhubungan dengan kewajiban pemeran, sedangkan tuntutan peranan (role demands) merupakan dorongan sosial yang merancang perilaku individu untuk memenuhi peranan yang diberikan. Kemampuan sandiwara (role skills) terbagi menjadi dua, yaitu kemampuan untuk membaca peranan orang lain (kemampuan kognitif), dan kemampuan untuk bersandiwara sesuai ekspektasi.

Dari sisi loyalitas atau Engagement, teori yang digunakan adalah Empoloyee Enggagement Model dari Aon Hewit. Employee Engagement yang didefinisikan oleh Aon Hewitt mengacu pada keadaan psikologis karyawan di dalam perusahaan atau organisasi yang dapat menentukan perilaku dan hasil kinerjanya. Selanjutnya Engagement Behavior akan tercermin dari Say (ucapan tentang perusahaan, kolega dan pelanggan), Stay (bagaimana individu ingin menjadi bagian dari organisasi), dan Strive (motivasi individu untuk berkontribusi terhadap organisasi). Model keterlibatan karyawan akan mendeteksi relasi atau konflik dalam lingkungan kerja karyawan dan cara mengatasi konflik antar karyawan atau antara karyawan dengan atasan (Fernando et al., 2019). Dalam penelitian ini, Enggagement Behavior yang diulas hanya dari sisi Stay dan Strive. Terdapat enam drivers penting yang dapat mempengaruhi Engagement Behaviour (outcome) yang dibahas dalam gambar 1 berikut: 


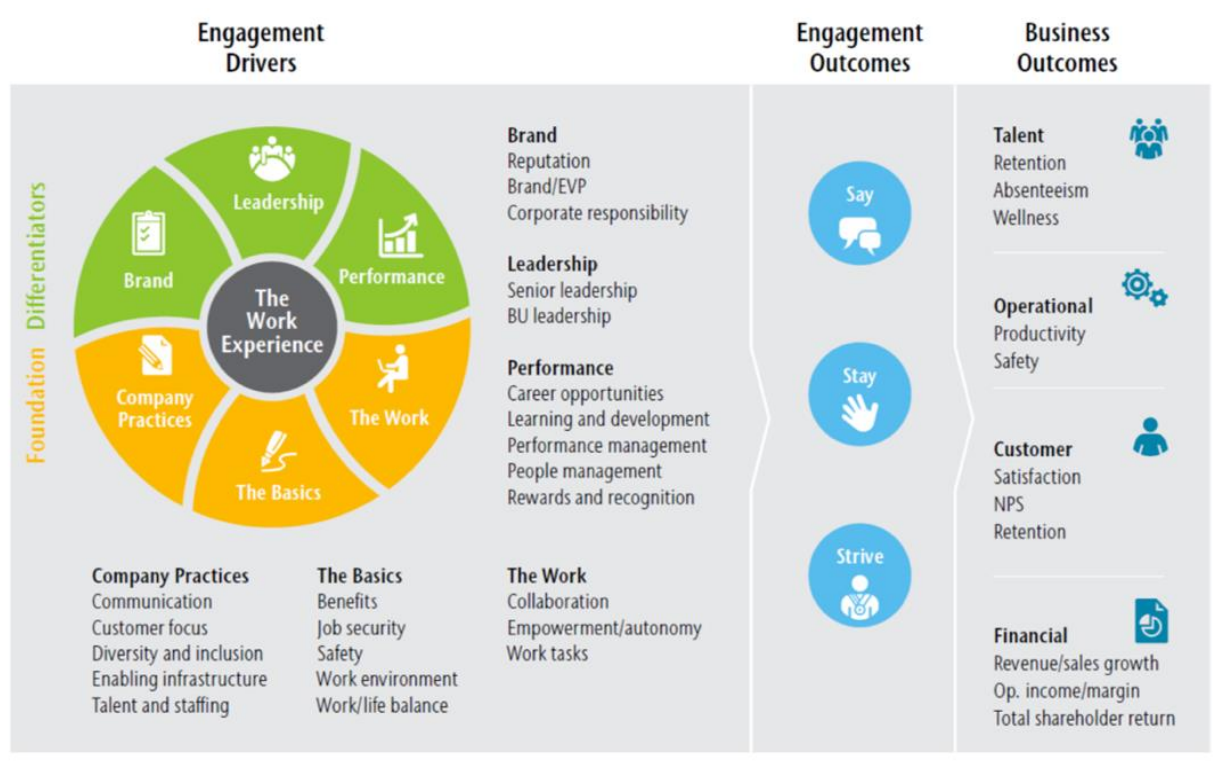

Gambar 2.

Aon Hewitt Engagement Model

Sumber: (AON Hewitt, 2015)

Hasil penelitian Gallup pada tahun 2013 di dalam State of America's Schools Report menemukan bahwa $31 \%$ guru di Amerika Serikat (AS) engaged dalam pekerjaan mereka, artinya hanya dari satu dari tiga guru yang antusias dan memiliki komitmen pada pekerjaan dan sekolah mereka (Gordon, 2013). Sisanya sebesar 56\% tidak memiliki memiliki semangat dan komitmen, mereka hanya sekedar menjalankan aktivitas sehari sehari (unengaged). Sisanya 13\% melepaskan diri dari tanggung jawab sebagai guru (actively unengaged). Komodifikasi ini mempengaruhi sistem pengajaran di Amerika Serikat dalam tingkatan serius (Yusriyah et al., 2020).

Penelitian Timothy Mutua Kilonzo (2018) pada Sekolah Menengah Pertama (Secondary School) menyimpulkan bahwa adanya korelasi positif antara employee engagement dengan kinerja (performance) guru, artinya semakin meningkat engagement guru maka kinerja guru akan turut meningkat (Mutua Kilonzo et al., 2018). Bahkan Barreiro (2020) menegaskan bahwa keterlibatan guru yang tinggi dapat berkontribusi positif terhadap sistem belajar mengajar dalam kelas (Barreiro \& Treglown, 2020).

Penelitian ini bertujuan untuk mengkaji peran komunikasi atasan (Kepala Sekolah) terhadap loyalitas atau Engagement Behavior para guru SAB dibandingkan dengan faktor pendorong (drivers) lainnya. dengan pertanyaan penelitian atau rumusan masalah adalah bagaimana peran komunikasi atasan atau Kepala Sekolah terhadap loyalitas (Stay Behaviour) dan semangat untuk bekerja dengan baik (Strive Behavior) pada Guru- Guru di Sekolah Alam Bandung (SAB). Terlampir kerangka pemikiran daripada penelitian yang akan dikonduksi: 


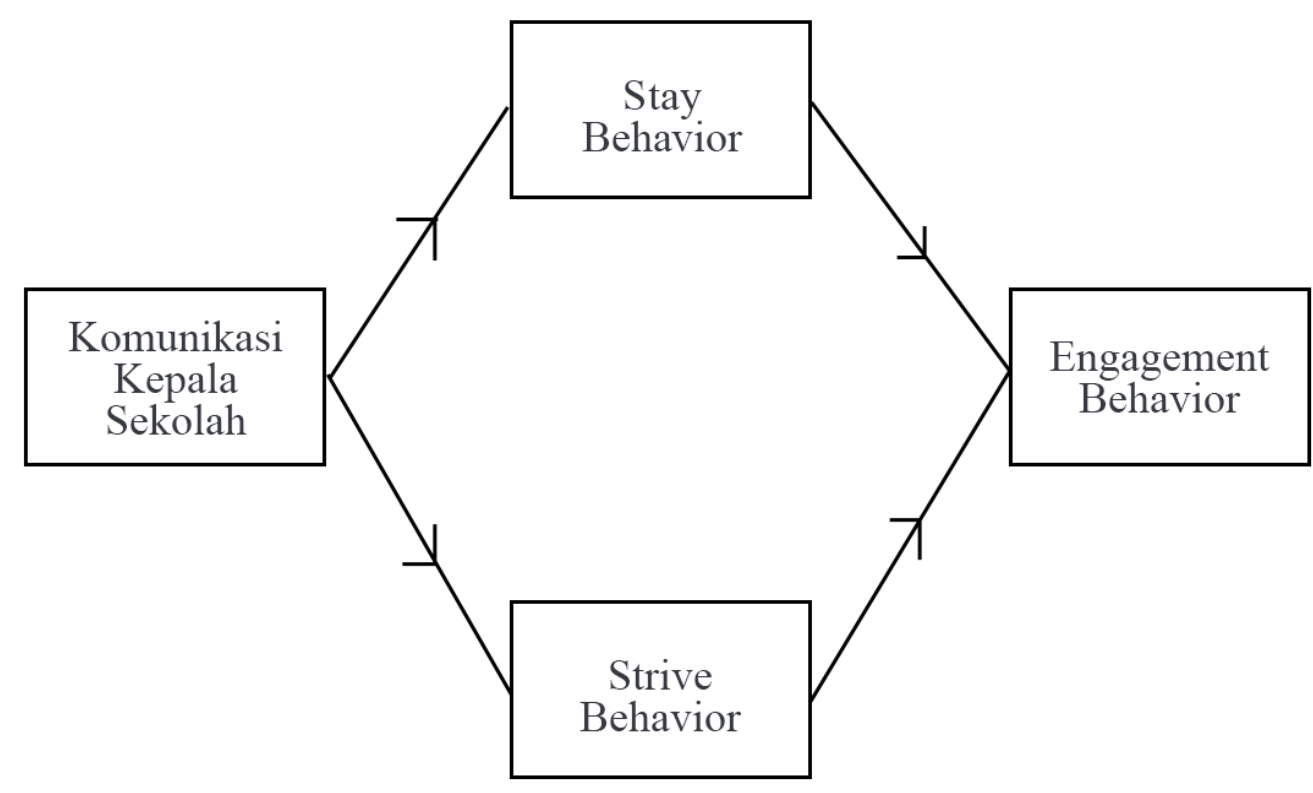

Gambar 3.

Kerangka Penelitian

Sumber: (Hasil Olahan Peneliti, 2020)

Hasil penelitian diharapkan dapat digunakan untuk menyusun kebijakan SAB untuk mempertahankan guru - guru yang berkualitas.

\section{Metodologi Penelitian}

Penelitian ini menggunakan pendekatan kuantitatif dengan teknik analisis Regresi Berganda melalui SPSS 25. Statistik deskriptif pada penelitian ini memberikan gambaran mengenai profil responden menurut umur, status perkawinan, jenis kelamin dan tingkat pendidikan. Teknik Regresi Linier Berganda digunakan untuk memprediksi hasil variabel yang diuji, yang bertujuan untuk membahas korelasi variabel bebas dan variabel terikat. Data akan diolah terlebih dahulu melalui uji validitas, uji reliabilitas, uji multikolinieritas, uji autokorelasi, dan uji heteroskedastis.

Data primer diperkumpulkan melalui kuesioner dan wawancara dengan kepala sekolah dan salah satu pendiri dan Pembina Sekolah Alam Bandung, serta data internal SAB. Sementara data sekunder diperkumpulkan dari kajian pustaka yang berkaitan dengan objek penelitian. Teknik sampling berupa sebuah sensus (total sampling) yang berjumlah 34 orang guru SAB.

Kuesioner disusun dengan mengacu pada skala likert dimana nilai 5 = Sangat Setuju, 4 = Setuju, 3 = Netral, 2 = Tidak Setuju, dan 1 = Sangat Tidak Setuju. Jumlah pertanyaan dalam kuesioner adalah 37 pertanyaan, dan 7 pertanyaan tertutup. 


\section{Hasil Penelitian}

Hasil data yang terkumpul dari kuesioner yang di uji terlebih dahulu dengan Test Validitas, Reliabilitas, Multikolineritas, Autokorelasi dan Heterokedasitas, dan hasilnya telah memenuhi syarat untuk dapat dilakukan analisis lebih lanjut dengan Metode Regressi Berganda. Hasil uji Determinasi (R Square) menunjukkan bahwa seluruh variabel operasional Employee engagement Drivers yang terdiri dari Company Brand, Leadership, Performance, the Work, the Basic, dan Company Practice berpengaruh secara simultan (mempengaruhi secara bersama - sama) baik terhadap Stay maupun Strive Behaviour, dengan nilai masingmasing sebesar $92,2 \%$ dan $83,8 \%$.

Berdasarkan nilai t-test tertinggi dikombinasi dengan skor rata-rata terendah (the lowest average low score) dari kuesioner berdasarkan Skala Likert, diperoleh peringkat Engagement Sub Drivers yang mempengaruhi Engagement Behaviour Stay dan Strive (Dependent Variable) sebagaimana yang tertera dalam tabel berikut. Pada tabel 1, dapat dilihat bahwa drivers yang paling berpengaruh terhadap Stay Behavior adalah Company Practice (Diversity \& Inclusion and Communication). Sedangkan, Engagement Drivers yang paling mempengaruhi Strive adalah Leadership (Coaching).

Peneliti memilih Engagement driver yang paling berpengaruh terhadap Engagement Behaviour untuk dianalisis lebih lanjut, yaitu Company Practice untuk Stay dan Leaderhip untuk Strive.

Tabel 1

Peringkat Engagement Driver Terhadap Engagement Behavior

\begin{tabular}{|l|l|l|}
\hline \multicolumn{1}{|c|}{ Ranking } & \multicolumn{1}{|c|}{ "STAY" } & \multicolumn{1}{|c|}{ "STRIVE" } \\
\hline 1 (Most Influencing) & Company Practice & Leadership \\
\hline 2 & Leadership & The Work \\
\hline 3 & Company Brand & Personal Value \\
\hline 4 & The Basic & Performance \\
\hline 5 & Performance & Company Brand \\
\hline 6 & The Work & Company Practice \\
\hline 7 (Least Influencing) & Personal Value & The Basic \\
\hline \multicolumn{2}{|c|}{ Sumber: olahan peneliti }
\end{tabular}

Diversity \& Inclusion didalam kuesioner dinyatakan sebagai pendapat bawahan diperhitungkan dalam kerjama tim, serta apresiasi perbedaan suku, agama, ras dan antar golongan yang mempengaruhi secara signifikan terhadap Stay Behaviour, mengingat terdapat sebuah identitas kelompok pekerja yang dihubungkan dengan suku, ras dan agama (Khairani et al., 2020). Di sisi lain untuk leadership (coaching), dinyatakan sebagai perhatian atasan 
terhadap kinerja bawahan dan kemampuan atasan dalam membentuk dan membina kerjasama tim, yang selanjutnya mempengaruhi Strive Behavior.

Dari tabel 1 juga dapat ditemukan bahwa komunikasi atasan ke bawahan lebih penting pengaruhnya dibandingkan dengan Gaji, lembur dan tunjangan lainnya serta lingkungan kerja (komponen The Basic). Demikian juga dengan aspek beban kerja (The Work) pengaruhnya lebih kecil dibandingkan aspek komunikasi.

Dilihat dari sisi masa kerja, maka pengaruh komunikasi atasan dapat dibagi menjadi beberapa kategori berdasarkan masa kerjanya yaitu lebih dari 10 tahun, antara 5-10 tahun dan dibawah satu tahun. Sedangkan untuk Engagement Behavior akan dibagi berdasaran Stay dan Strive Behaviour. Saat ini komposisi masa kerja lebih dari 10 tahun, antara 5-10 tahun, dan dibawah 5 tahun masings sebesar $14,7 \%, 20,6 \%$ dan $64,7 \%$.

Stay Behaviour: Masa Kerja lebih dari 10 tahun, tabel 2 berikut menggambarkan guru bekerja lebih dari 10 tahun dan akan tetap tinggal (Stay) di SAB karena alasan pendapat mereka selalu dipertimbangkan dalam pengambilan keputusan kerja tim.

Tabel 2

Stay Behavior Guru Berdasarkan Masa Kerja Lebih dari 10 Tahun

\begin{tabular}{|c|l|l|c|l|c|}
\hline Drivers & \multicolumn{1}{|c|}{$\begin{array}{c}\text { Sub- } \\
\text { Driver }\end{array}$} & Detail of the statement & $\begin{array}{c}\text { Average } \\
\text { Score }\end{array}$ & $\begin{array}{l}\text { Statement Engagement } \\
\text { Behavior STAY }\end{array}$ & $\begin{array}{c}\text { Average } \\
\text { Score }\end{array}$ \\
\hline $\begin{array}{c}\text { Company } \\
\text { Practice }\end{array}$ & $\begin{array}{l}\text { Diversity } \\
\text { \& }\end{array}$ & $\begin{array}{l}\text { X1.17. Saya merasa } \\
\text { pendapat saya selalu } \\
\text { diperhitungkan dalam } \\
\text { kerja sama tim. }\end{array}$ & 3.8 & $\begin{array}{l}\text { X2.34. Butuh banyak } \\
\text { pertimbangan untuk } \\
\text { membuat saya } \\
\text { meninggalkan SAB }\end{array}$ & 4.2 \\
& & & & & \\
\hline
\end{tabular}

Sumber: olahan peneliti

Masa Kerja antara 5 - 10 tahun, alasan utama para Guru yang bekerja selama 5 sampai 10 tahun akan tinggal (Stay) di SAB, adalah karena SAB menghargai perbedaan suku, agama, ras dan antar golongan yang mencerminkan keragaman latar belakang guru sebagai bentuk identitas kelompok guru, seperti yang tertera dalam tabel 3.

Tabel 3

Stay Behavior Guru Dengan Masa Kerja antara 5 - 10 tahun

\begin{tabular}{|c|c|c|c|c|c|}
\hline Drivers & $\begin{array}{c}\text { Sub- } \\
\text { Driver }\end{array}$ & $\begin{array}{c}\text { Detail of the } \\
\text { statement }\end{array}$ & $\begin{array}{c}\text { Average } \\
\text { Score }\end{array}$ & $\begin{array}{c}\text { Statement Engagement } \\
\text { Behavior STAY }\end{array}$ & $\begin{array}{c}\text { Average } \\
\text { Score }\end{array}$ \\
\hline $\begin{array}{l}\text { Company } \\
\text { Practice }\end{array}$ & $\begin{array}{l}\text { Diversity } \\
\& \\
\text { Inclusion }\end{array}$ & $\begin{array}{l}\text { X1.18. SAB } \\
\text { menghargai } \\
\text { perbedaan suku, } \\
\text { agama, ras dan antar } \\
\text { golongan. }\end{array}$ & 3.9 & $\begin{array}{l}\text { X2.34. Butuh banyak } \\
\text { pertimbangan } \\
\text { membuat saya meninggalkan } \\
\text { SAB }\end{array}$ & 3.9 \\
\hline
\end{tabular}

Sumber: olahan peneliti 
Masa Kerja Kurang dari 5 tahun, tabel 4 berikut menjelaskan bahwa guru yang bekerja kurang dari 5 tahun merasa pendapat mereka selalu dipertimbangkan dalam pengambilan keputusan tim, oleh karena itu mereka berniat untuk tetap bekerja di SAB.

Tabel 4

Stay Behavior Guru dengan Masa Kerja Kurang dari 5 Tahun

\begin{tabular}{|c|c|c|c|c|c|}
\hline Drivers & Sub-Driver & $\begin{array}{c}\text { Detail of the } \\
\text { statement }\end{array}$ & $\begin{array}{l}\text { Averag } \\
\text { e Score }\end{array}$ & $\begin{array}{c}\text { Statement Engagement } \\
\text { Behavior STAY }\end{array}$ & $\begin{array}{l}\text { Average } \\
\text { Score }\end{array}$ \\
\hline $\begin{array}{l}\text { Company } \\
\text { Practice }\end{array}$ & $\begin{array}{l}\text { Diversity } \\
\& \\
\text { Inclusion }\end{array}$ & $\begin{array}{l}\text { X1.17. Saya merasa } \\
\text { pendapat saya selalu } \\
\text { diperhitungkan } \\
\text { dalam kerja sama tim. }\end{array}$ & 3.7 & $\begin{array}{l}\text { X2.34. Butuh } \\
\text { banyak } \\
\text { pertimbangan } \\
\text { untuk membuat } \\
\text { saya } \\
\text { meninggalkan } \\
\text { SAB }\end{array}$ & 3.8 \\
\hline
\end{tabular}

Sumber: olahan peneliti

Strive Behaviour. Masa Kerja Lebih dari 10 Tahun, seperti terlihat pada tabel 5 berikut ini, guru yang bekerja lebih dari 10 tahun merasa bahwa atasan memberi perhatian terhadap kinerja mereka, disamping kemampuan atasan untuk membentuk dan membina kerjasama antar tim. Dengan alasan ini responden merasa terinspirasi dan termotivasi untuk bekerja lebih baik.

Tabel 5

Strive Behavior Guru dengan Masa Kerja lebih dari 10 Tahun

\begin{tabular}{|l|l|l|l|l|l|}
\hline Drivers & Sub-Driver & Detail of the statement & $\begin{array}{l}\text { Average } \\
\text { Score }\end{array}$ & $\begin{array}{l}\text { Statement Engagement } \\
\text { Behavior STRIVE }\end{array}$ & $\begin{array}{l}\text { Average } \\
\text { Score }\end{array}$ \\
\hline Leadership & $\begin{array}{l}\text { Senior } \\
\text { Leadership }\end{array}$ & $\begin{array}{l}\text { X1.5. Atasan saya } \\
\text { memberikan perhatian } \\
\text { terhadap kinerja }\end{array}$ & 4 & $\begin{array}{l}\text { X2.36. SAB } \\
\text { menginspirasi saya } \\
\text { untuk bekerja sebaik } \\
\text { mungkin setiap hari. }\end{array}$ & 4 \\
\cline { 2 - 6 } & $\begin{array}{l}\text { Mission \& } \\
\text { Objective }\end{array}$ & $\begin{array}{l}\text { X1.7. Atasan saya } \\
\text { mampu membentuk } \\
\text { dan membina } \\
\text { kerjasama antar tim. }\end{array}$ & 4 & $\begin{array}{l}\text { X2.27. Saya termotivasi } \\
\text { untuk melakukan yang } \\
\text { terbaik dalam pekerjaan } \\
\text { saya. }\end{array}$ & 4 \\
\hline
\end{tabular}

Sumber: olahan peneliti

Masa Kerja antara 5-10 tahun, alasan guru yang bekerja selama lima hingga sepuluh tahun terinspirasi untuk melakukan tugas terbaiknya adalah karena adanya perhatian yang baik dari atasan terhadap kinerja mereka, yang tertera dalam tabel berikut:

Tabel 6

Strive Behavior Guru dengan Masa Kerja antara 5 - 10 Tahun

\begin{tabular}{|l|l|l|l|l|l|}
\hline Drivers & Sub-Driver & $\begin{array}{l}\text { Detail of the } \\
\text { statement }\end{array}$ & $\begin{array}{l}\text { Average } \\
\text { Score }\end{array}$ & $\begin{array}{l}\text { Statement Engagement } \\
\text { Behavior STRIVE }\end{array}$ & $\begin{array}{l}\text { Average } \\
\text { Score }\end{array}$ \\
\hline Leadership & $\begin{array}{l}\text { Senior } \\
\text { Leadership }\end{array}$ & $\begin{array}{l}\text { X1.5. Atasan saya } \\
\text { memberikan perhatian } \\
\text { terhadap kinerja }\end{array}$ & 3.4 & $\begin{array}{l}\text { X2.36. SAB menginspirasi } \\
\text { saya untuk bekerja sebaik } \\
\text { mungkin setiap hari. }\end{array}$ & 4 \\
& & & & \\
\hline
\end{tabular}


Masa Kerja Kurang dari lima tahun untuk guru yang masa kerjanya kurang dari 5 tahun, responden merasa terinspirasi untuk bekerja dengan baik karena alasan perhatian atasan terhadap kinerja mereka. Alasan ini sama dengan dengan para senior mereka yang telah bekerja lebih dari 5 tahun.

Tabel 7

Strive Behavior Guru dengan Masa Kerja Kurang dari 5 tahun

\begin{tabular}{|l|l|l|l|l|l|}
\hline Drivers & Sub-Driver & Detail of the statement & $\begin{array}{l}\text { Average } \\
\text { Score }\end{array}$ & $\begin{array}{l}\text { Statement Engagement } \\
\text { Behavior STRIVE }\end{array}$ & $\begin{array}{l}\text { Average } \\
\text { Score }\end{array}$ \\
\hline Leadership & $\begin{array}{l}\text { Senior } \\
\text { Leadership }\end{array}$ & $\begin{array}{l}\text { X1.5. Atasan saya } \\
\text { memberikan perhatian } \\
\text { terhadap kinerja }\end{array}$ & 3.6 & $\begin{array}{l}\text { X2.36. SAB } \\
\text { menginspirasi saya untuk } \\
\text { bekerja sebaik mungkin } \\
\text { setiap hari. }\end{array}$ & 3.6 \\
\cline { 2 - 4 } & $\begin{array}{l}\text { Mission \& } \\
\text { Objective }\end{array}$ & $\begin{array}{l}\text { X1.7. Atasan saya } \\
\text { mampu membentuk dan } \\
\text { membina kerjasama } \\
\text { antar tim. }\end{array}$ & 3.6 & & \\
\hline
\end{tabular}

Sumber: olahan peneliti

Dari hasil uraian di atas, dapat diambil temuan penelitian beberapa alasan guru bersedia tetap bekerja (Stay) dan atau bersedia bekerja dengan baik (Strive) di SAB, berdasarkan kategori masa kerja adalah sebagai berikut:

a. Alasan para guru tetap bertahan (Stay) mengajar di SAB.

Untuk guru yang bekerja di atas 10 tahun memiliki alasan yang sama dengan guru yang bekerja kurang dari 5 tahun, yaitu mereka merasa pendapatnya dihargai di dalam tim kerja. Sedangkan untuk guru yang masa kerjanya antara 5 sampai dengan 10 tahun, alasan untuk tetap bekerja di SAB adalah karena adanya keberagaman dan saling menghargai latar belakang termasuk suku, latar belakang organisasi keagamaan dan atar belakang pendidikan S-1 yang bervariasi).

b. Alasan para guru memiliki motivasi bekerja dengan baik (Strive) di SAB.

Semua guru merasa bahwa atasannya (Kepala Sekolah) memberikan perhatian yang baik dan mendukung pekerjaan mereka. Adapun alasan tambahan berdasarkan kategori masa kerja untuk guru senior (bekerja lebih dari 10 tahun) dan guru yunior (bekerja dibawah 5 tahun), adalah atasan/(Kepala Sekolah) dianggap mampu membentuk dan membina kerjasama antar tim. 


\section{Pembahasan}

Berdasarkan uraian temuan penelitian tersebut, interpretasi yang dapat ditelusuri bersama bahwa penghargaan dan perhatian terhadap bawahan dari atasan/ Kepala Sekolah lebih berpengaruh terhadap loyalitas dan semangat atau engagement behavior para guru dibandingkan dengan faktor (drivers) lainnya seperti gaji, lingkungan kerja dan beban kerja. Kepala Sekolah di SAB seluruhnya adalah mantan guru yang dipilih oleh Yayasan, artinya seorang guru yang diangkat menjadi kepala sekolah harus menyesuaikan dengan peran barunya sebagai Kepala Sekolah dan berhadapan dengan bawahan yang sebelumnya adalah rekan kerja, bahkan ada yang menjadi seniornya. Perubahan peran ini tentu memerlukan kemampuan komunikasi yang mumpuni.

Perubahan peran dan komunikasi Kepala Sekolah tersebut dapat dijelaskan dengan model Komunikasi Interpersonal yaitu Model Peranan, dimana hubungan interpersonal terjalin secara efektif apabila individu mampu bersandiwara sesuai dengan harapan yang memenuhi tuntutan dari peranan individu serta memiliki keterampilan selama bersandiwara (Asrarudin et al., 2020).

Tugas dan kewajiban Kepala Sekolah tentu berbeda dengan seorang guru. Peran ini ternyata mampu dimainkan oleh para Kepala Sekolah yang dulunya adalah mantan guru. Peran tersebut antara lain adalah memimpin briefing dan coaching yang dilakukan setiap pagi untuk membahas apa yang telah diselesaikan dan apa yang harus diselesaikan serta memberikan inspirasi terkait dengan proses belajar mengajar, misalnya dengan mensitir ayat Al Quran tentang perlunya bersikap sabar. Selain itu, Kepala Sekolah secara rutin melakukan peninjauan pelaksanaan proses belajar, sehingga kendala -kendala di lapangan dapat diketahui secara dini. Untuk mendukung kedekatan hubungan interpersonal, Kepala Sekolah juga melakukan gathering atau pertemuan informal untuk lebih memahami persepsi para guru dan menjadi pendengar yang baik terhadap masukan - masukan yang diberikan oleh bawahannya.

Kepala sekolah sebagai atasan sudah seharusnya mampu menjadi pendengar yang baik. Untuk dapat memahami dan menghargai bawahannya dengan baik adalah dengan mendengarkan apa yang disampaikan anak buah sampai selesai dan tidak malakukan interupsi, agar tidak terjadi kesalahan persepsi (Hardjati \& Febrianita, 2019). Disamping itu, seorang Kepala Sekolah sebaiknya mampu memahami apa yang tidak dikatakan, dengan kata lain memperhatikan keselarasan bahasa verbal (lisan) dan non-verbal seperti bahasa tubuh, karena pesan dari bawahan seringkali tidak terungkap dari apa yang dikatakan secara langsung tapi justru dari apa yang tidak dikatakan, seperti yang tercantum dalam tabel 5 dimana terdapat atensi kepala sekolah yang memotivasi guru untuk memberikan performa lebih baik. Menurut 
salah satu pakar Management yaitu Peter Drucker, aspek terpenting dalam komunikasi adalah kemampuan untuk membaca apa yang tidak diucapkan.

\section{Kesimpulan}

Peran komunikasi Kepala Sekolah sebagai atasan terhadap kesetiaan atau Stay Behaviour dan semangat untuk bekerja dengan baik (Strive Behavior) guru SAB lebih berpengaruh dibandingkan dengan faktor lainnnya seperti gaji, lingkungan kerja dan beban kerja. Para guru menilai bahwa Kepala Sekolah sebagai atasannya dinilai dapat menghargai pendapat mereka dalam pengambilan keputusan dalam tim, sehingga dibutuhkan banyak pertimbangan untuk meninggalkan pekerjaannya di SAB. Selain itu atasan dinilai mampu memberikan perhatian terhadap kinerja para guru, dan perhatian tersebut memberikan inspirasi dan motivasi untuk bekerja lebih baik lagi.Penilaian guru sebagai bawahan terhadap atasannya menunjukan bahwa Kepala Sekolah yang sebelumnya adalah guru, telah mampu memainkan perannya sesuai harapan bawahannya, serta memiliki keterampilan sebagai seorang Kepala Sekolah, termasuk ketrampilan berkomunikasi.

\section{Daftar Pustaka}

AON Hewitt. (2015). Aon Hewitt's model of employee engagement. Aon Inc., January, 1-9. https://www.aonhewitt.co.nz/getattachment/77046028-9992-4d77-868a$32 \mathrm{fbf} 622 \mathrm{fec} 6 /$ file.aspx ?disposition=inline

Asrarudin, Purwana, D., \& Madhakomala, R. (2020). Do Transformational Leadership, Interpersonal Communication, and Career Development Have Direct and Indirect Effect on Diplomats' Organizational Commitment at the Ministry of Foreign Affairs Republic of Indonesia in Jakarta? IJHCM (International Journal of Human Capital Management), 4(1), 59-73. https://doi.org/10.21009/ijhcm.04.01.05

Barreiro, C. A., \& Treglown, L. (2020). What makes an engaged employee? A facet-level approach to trait emotional intelligence as a predictor of employee engagement. Personality and Individual Differences, 159(November 2019), 109892. https://doi.org/10.1016/j.paid.2020.109892

Budaya, K. P. dan. (2020). Data Pokok Sekolah Alam Bandung. Data Pokok Pendidikan. https://dapo.kemdikbud.go.id/sekolah/D71B5D4B25C638974E7A

Darling-Hammond, L. (2003). Keeping good teachers: Why it matters, what leaders can do. Educational Leadership, 60(8), 6-13. 
Dewi, S. P., \& Hidayat, R. (2014). Pengaruh Net Profit Margin dan Return on Assets terhadap Harga Saham pada Perusahaan Otomotif yang Terdaftar di Bursa Efek Indonesia. Ilman.

Fernando, J., Marta, R. F., \& Hidayati, R. K. (2020). Reaktualisasi mahasiswa diaspora Indonesia dalam menjaga identitas budaya bangsa di Benua Australia. Jurnal Kajian Komunikasi, 8(2), 194-206. https://doi.org/https://doi.org/10.24198/jkk.v8i2.25219

Fernando, J., Marta, R. F., \& Sadono, T. P. (2019). Resolusi Konflik Melalui Model Pengampunan Vita Activa Arendt Dalam Komunikasi Generasi Muda Kalimantan Barat. Jurnal ASPIKOM, 4(1), 113. https://doi.org/10.24329/aspikom.v4i1.511

Gordon, G. (2013). SCHOOL LEADERSHIP LINKED TO ENGAGEMENT AND STUDENT ACHIEVEMENT. Gallup, 1(July), 24.

Hamadani, A. (2015). Sekolah Alam: Alternatif Pendidikan Ramah Anak. Jurnal Harkat: Media Komunikasi Gender, 11(1), 86-95. https://doi.org/10.15408/harkat.v15i1.10433

Hardjati, S., \& Febrianita, R. (2019). The Power of Interpersonal Communication Skill in Enhancing Service Provision. Journal of Social Science Research, 14, 3192-3199.

Khairani, L., Muhammadiyah, U., \& Utara, S. (2020). DINAMIKA KONTESTATIF DALAM REPRODUKSI IDENTITAS. Seminar of Social Sciences Engineering \& Humaniora, 19, 194-203.

Marta, R. F., Fernando, J., \& Kurniawati, L. S. M. W. (2020). Tinjauan Peran Komunikasi Keluarga Pada Kinerja Public Relations Melalui Konten Laman Resmi Media Daring Kpppa. Jurnal Komunikasi Pembangunan, 18(01), 30-42. https://doi.org/10.46937/18202028620

Murtiningsih, Kristiawan, M., \& Lian, B. (2019). The Correlation Between Supervision of Headmaster and Interpersonal Communication. European Journal of Education Studies, 6(1), 246-256. https://doi.org/10.5281/zenodo.2649535

Mutua Kilonzo, T., Were, S., \& Odhiambo, R. (2018). Influence of employee engagement on the performance of teachers in secondary schools in Machakos County in Kenya. International Journal of Novel Research in Humanity and Social Sciences, 5(1), 52-71. www.noveltyjournals.com

Price, H. E. (2012). Principal-teacher interactions: How affective relationships shape principal and teacher attitudes. Educational Administration Quarterly, 48(1), 39-85. https://doi.org/10.1177/0013161X11417126

Rahayu, S. (2017). Komunikasi Interpersonal Kepemimpinan Kepala Sekolah dan Budaya Kerja Organisasi terhadap Motivasi Kerja Dan Dampaknya pada Kepuasan Kerja Guru Sekolah Menengah Pertama. Manajemen Pendidikan, 12(1), 73. 
https://doi.org/10.23917/jmp.v12i1.2977

Riauan, M. A. I., Sari, G. G., Aziz, A., Prayuda, R., \& Sikumbang, A. T. (2020). REFLEKSI ANOMALI MAKNA PERILAKU MEROKOK DI KALANGAN DOSEN UNIVERSITAS ISLAM RIAU. Bricolage: Jurnal Magister Ilmu Komunikasi. https://doi.org/10.30813/bricolage.v6i02.2177

Rismi, R., Yustiana, Y., \& Budiman, N. (2020). The Effectiveness of Group Counseling with Role Play Techniques to Improve Student Emotional Intelligence. Jurnal Aplikasi IPTEK Indonesia, 4(2), 59-68. https://doi.org/10.24036/4.24331

Sari, Y., Zaman, B., \& Setiasih, O. (2018). PROFIL KREATIVITAS GURU DALAM MENGEMBANGKAN MEDIA PEMBELAJARAN (Studi Kasus pada Guru di Taman Kanak-Kanak Sekolah Alam Bandung). EDUKIDS: Jurnal Pertumbuhan, Perkembangan Dan Pendidikan Anak Usia Dini, 2(1), 103-112.

Sasongko, Y. P. D., \& Marta, R. F. (2018). Ekspresi Identitas Melalui Relasi Ayah Dan Anak Pada Iklan Youtube Grab Official. Bricolage : Jurnal Magister Ilmu Komunikasi, 4(02), 118. https://doi.org/10.30813/bricolage.v4i02.1656

Sereenonchai, S., \& Arunrat, N. (2021). Understanding Food Security Behaviors during the COVID-19 Pandemic in Thailand: A Review. Agronomy, 11(May 2020), 1-15.

Suherman, A., \& Suhardan, D. (2019). Interpersonal Communication between Principals and Teachers in Elementary Schools. 258(Icream 2018), 111-113. https://doi.org/10.2991/icream-18.2019.24

Supriadi, O. (2017). The Influence of Principal's Communication Skils and Quality of Leadership on Teachers' Job Satisfaction. Journal of Education and Practice, 8(29), 113. http://repository.unej.ac.id/bitstream/handle/123456789/65672/Ainul Latifah101810401034.pdf?sequence $=1$

Tabah Hati, S. (2017). MODEL PENDIDIKAN KARAKTER YANG BAIK DI SEKOLAH ALAM. IJTIMAIYAH Jurnal Ilmu Sosial Dan Budaya, 1-32.

Yusriyah, K., Fatoni, A., \& Mansyur, M. A. (2020). Communication Networks Analysis on Information Dissemination of the Moving of Capital City From Jakarta to East Kalimantan. Aspiration Journal. 